\title{
Role of Education in Building Social Cohesion
}

\author{
Zebun Nisa Khan \\ Department of Education, AMU Aligarh, India
}

Email address:

zebunnisakhan@yahoo.com

\section{To cite this article:}

Zebun Nisa Khan. Role of Education in Building Social Cohesion. International Journal of Secondary Education.

Vol. 4, No. 2, 2016, pp. 23-26. doi: 10.11648/j.ijsedu.20160402.12

Received: May 4, 2016; Accepted: May 19, 2016; Published: May 28, 2016

\begin{abstract}
Social Cohesion is the expression of that tradition of tolerance in all religions and cultures that are the basis of peace and progress. It is foreign to know culture and native to all nations. Tolerance and mercy have always and in all cultures being ideals of Government rules and human behavior. Professional educator often comments on the poor quality of education, politician and bureaucrats try to paint it as unproductive and a liability to the society. Social cohesion educational challenges are vital, crucial and powerful. We have to respond to the challenges immediately and continuously, so as to achieve the goals of democratic state.
\end{abstract}

Keywords: Social Cohesion, Marginalization, Interdependent, Infringements, Interdisciplinary, Adjudication

\section{Introduction}

The sociologist Emile Durkheim was the first who used the concept of social cohesion. According to him social cohesion is an ordering feature of a society. Social cohesion is the capacity of a society to ensure the well being of all its members, minimizing disparities and avoiding marginalization. ${ }^{l}$ In other words, we can say that it is the foundation of human existence and co-existence. Social cohesion is universal, indivisible, and interdependent and is principle by which we create the sacred home for human dignity.

Coordination for the implementation of the Decade's Plan of Action $^{2}$ has been entrusted to the United Nations High Commission for social cohesion. For the designing, implementation and evaluation of projects in the said plan, UNESCO should play a central role, and should collaborate with the high commissioners and the United Nation Centers for Social Cohesion. The memorandum of cooperation signed between Director General of UNESCO and the United Nations Commissioner for Social Cohesion in October 1995, envisaged close collaboration in implementing activities related to education for social cohesion and democracy.

Social cohesion has also been seen as contributing to

1 Report of High Level Task Force on Social Cohesion in $21^{\text {st }}$ Century.

2 Office of the High Commissioner for Human Rights (OHCHR), Resolution 49/154 (A/51/506/Add.1.appedix). cohesion and education is viewed as "the most powerful generator of social capital" in our society [3]. In view of [7], education is thought of providing such a bridging capital to individual. [9] examines the ways education is related to social cohesion, mainly in sociology of education approaches. Education is viewed as an important institution that contributes to cohesion by socializing the new members of the society, providing them with knowledge and skills in order to facilitate their social participation.

\section{Education for Social Cohesion}

The development of a comprehensive system of education for social cohesion, democracy \& peace, embracing all levels of education and available to all is the long-term objective of UNESCO. In other words, formal, non-formal and informal education is covered by the system evolved. By the combined efforts of educators, families, mass and intergovernmental and non-intergovernmental organizations a culture of social cohesion and democracy is to be evolved. [6] suggested the following in this regard:

- Education should cease to be considered as a one shot affair meant for children and youth.

- Education and work should be looked upon as complementary forces, which operate simultaneously throughout the entire life of an individual.

- All the three channels of education- fulltime, part-time 
and own-time should be developed in every state and in every sector of education and given equal status.

- Education should cease to be looked upon as a school process: it should be a social process covering all learning that take place, whether in or outside the school.

- Education should cease to be delegated responsibility of a profession and should become the direct social responsibility in which every individual is involved, both as a teacher and as a student.

- The right to learn should be assured to every individual, without any discrimination and with full equality of opportunity, and he should also receive all the support and facilities necessary for its effective exercise throughout his life.

- The non-formal sector, which has been neglected in the past, should be developed and blended with the formal sector in an integrated fashion to create a new system of education, which will have advantages of both the sectors and also eliminate the weakness, which arises when these sectors are developed in isolation.

\section{Human Right Education}

Government of India in 1993 introduced Protection of Human Right Act, which was brought into being the National Human Rights Commission (NHRC) to operate as the nodal agency for promoting and fostering the culture of human rights and to oversee the implementation and infringements of human rights, which also includes social cohesion. In addition to its statutory transformation, importance to education, training and environment building for human rights were the tasks taken by NHRC. The policy initiatives of the NHRC include the following:

- Dialogue with the Ministry of HRD (Department of Education) and NCERT as well as State Governments to pursue the question of human rights instruction at various levels of schooling.

- Preparation of a source book by NCERT on human right material for facilitating access by teachers and academics.

- Preparation of teacher training modules for pre-service and in-service stages by NCERT.

- Review of textbooks with a view to deleting from them references before that may be prejudicial to human rights and replacing them with material aimed at inculcating genuine sensitivity to and understanding of such rights.

- Dialogue with the University Grant Commission, Vicechancellors and Deans of Law Faculties suggesting that human rights find a place both in undergraduate and postgraduate courses.

- Promotion and cooperation with NGOs active in this sphere.

- Special emphasis on orientation and training of officers and men of the armed forces, paramilitary forces and the police to sensitize them to human rights.

\section{Contribution of Education}

Social cohesion education is interdisciplinary in nature. It involves the subject areas of Education, Management, Economics, Political Science, Sociology, History, Commerce, Geography, and Philosophy etc. The significance of social cohesion in the socio-economic cultural development of India has not been fully recognized by the society as well as by the system. None of the faculties (Science/Social Science) like to take the responsibility of sharing the task. Each faculty of study feels that it is outside its scope of study. Interdisciplinary approach is totally lacking. According to [8] the meaning of education is not to educate people in the thing of which they are ignorant. The real meaning of education is to teach people to conduct themselves in ways in which they do not behave, while [4] is of the opinion that education may be both conservative by nature and progressive by design.

According to [8] social cohesion is a term used to denote that a complex whole such as society has reached a level of equilibrium and stability. How does education could help to transform society in order to achieve a better and more just world? [10] gives the answer of the above and emphasized that most commonly today education is used to learn craft and receive expertise in order to secure employment. To my opinion such an effect to education shall undoubtedly contribute to retaining social cohesion and peace for longer period of time.

Education should contribute to social cohesion in the following ways ${ }^{3}$.

- Schools ought to teach the rules of the game: those that govern interpersonal and political action. They consist of the social and legal principles underpinning good citizenship, obligations of political leaders, behavior expected of citizens, and consequences for not adhering to these principles. Schools can also facilitate a student's appreciation for the complexity of issues related to historical and global current events and, in so doing, may increase the likelihood that a student will see a point of view other than his or her own. By teaching the rules of the game in this manner, schools foster tolerance and lay the groundwork for voluntary behavior consistent with social norms.

- Schools are also expected to provide an experience roughly consistent with those citizenship principles, in effect, decreasing the "distance" between individuals of different origins. The educational experience derives from a wide variety of activities, whether in the classroom, the hallway, schoolyard, playing field, or bus. The degree to which a school may do this well depends on its ability to design the formal curriculum, its culture, and the social capital of its surrounding community. The purpose for providing experiences that are consistent with the principles of citizenship is clear.

\footnotetext{
3 Social Cohesion and Education - Background: Social Cohesion and Development, Social Functions of Education - Schools, Public, School, and Rights - StateUniversity.com. http://education.stateuniversity.com /pages/2428/Social-Cohesion-Education.html\#ixzz43wP9dCHo
} 
Both formal and informal social contracts require elements of trust among strangers-to the extent that the socialization of citizens from different social origins allows them to acknowledge and respect each other; that is, decreasing the "distance." If the educational task is done effectively, this allows political institutions to adjudicate differences and economic institutions to operate efficiently.

- School systems are expected to provide an equality of opportunity for all students. If the public perceives that the school system is biased and unfair, then the trust that citizens place in various other public institutions is compromised. For instance, the willingness of adults to play by the rules of the game may be compromised if fairness in the system appears suspect.

- Public schools are expected to incorporate the interests and objectives of many different groups and at the same time attempt to provide a common underpinning for citizenship. Often there are disagreements over the balance between these objectives. These disagreements must be adjudicated. Adjudication can be accomplished through many mechanisms-public school boards, professional councils, parent-teacher associations. The success of a school system is based in part on its ability to garner public support and consensus, and hence its ability to adjudicate differences over educational objectives.

\section{Role of Higher Education}

It is the India's education system; which can introduce the social cohesion education in the Universities especially at higher level. According to [3] the following activities for higher education institutions in India for the human rights, which includes social cohesion. Some of the suggestion given below does come under the purview of the social cohesion:

- Survey of awareness about human rights among college and university students, college and university teachers, parents, school teachers, school students, educational administrators, SC population, ST population, people remaining below poverty line, child laborers and their parents, politicians, Panchayati Raj representatives, etc.

- Organizing exhibitions on the different aspects of constitutional provisions and their violation.

- Carry out evaluation of textbooks in the light of human right violation.

- Evaluating classroom activities of the teacher in the light of the right of the child.

- Studying newspaper report on violation of human rights.

- Studying the problems concerning non-enrolment of the children in school and developing plan of action to solve the problem.

- Evaluating activities such as one act plays, street plays, etc portraying various aspects of human rights.

- Organizing public meetings in the locality to develop awareness of public on human rights.

- Studying different religious practices and activities of
God-men that violate human rights.

- Studying the problems of the girl's students in coeducational institutions.

- Studying the problem of women teachers in coeducational school and colleges.

- Studying the revision for equal opportunity in education.

- Studying the conditions of work at home and other work sites.

- Studying the superstitions existing in the locality.

- Providing courses on human rights education.

- Studying the NFE program with reference to the rights of the child to get basic education.

- Studying the extent of punishment given in schools that dissuade a child from attending school.

\section{Conclusion}

Today's education systems were introduced in 18th and 19th Century in the western world and were adopted by other nations accordingly. Government of India introduced a bill for the betterment of the education for all. The Right of Children to Free and Compulsory Education Act or Right to Education Act (RTE), is an Act of the Parliament of India enacted on 4 August 2009, which describes the modalities of the importance of free and compulsory education for children between 6 and 14 in India under Article 21A of the Indian Constitution. India became one of 135 countries to make education a fundamental right of every child when the act came into force on 1 April 2010. In comprehensive system of schooling equality of education is very much important to promote social cohesion in comparison to selective educational system. Education and social cohesion are closely linked to each other. Education trains the people for preserving society for the upcoming generation. Education contributes to maintain social order and affect the social cohesion. Education is one of the important tools, which is available to many affects the academic achievement of the pupils and enhances the society as well as social cohesion. Education system needs an improvement to meet the needs of the population for the enhancement of their academic achievement. It will thus give them opportunity to live together in peace in the country and thus will have an impact on social cohesion.

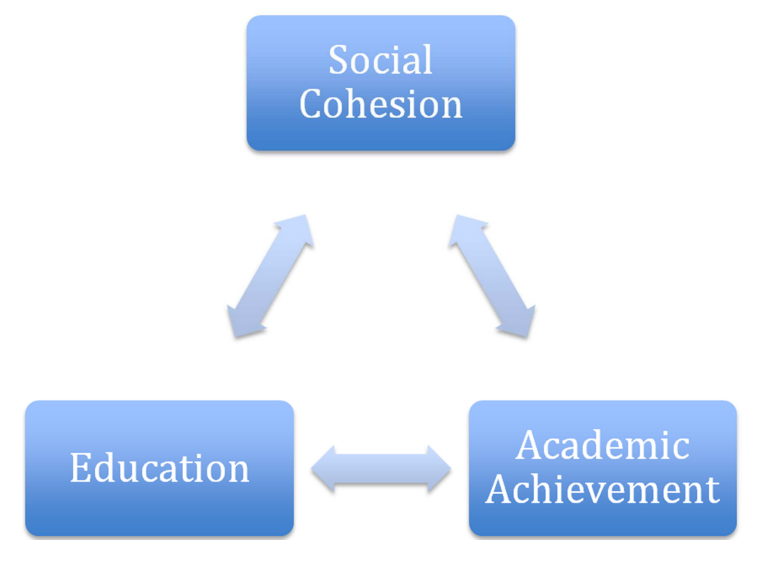

Social Cohesion Cycle w $\mathrm{r} t$ to Education and Academic Achievement 
By adopting the above policy measures the methods of study constitutes the social cohesion also. Despite the introduction of the above education policy, the progress in this regard is not satisfactory. Many factors lay at the root of this situation.

Different approaches from different angles and point of views were used to define social cohesion. The concept of social cohesion points to a level of analysis that commonly called macro [1].

Keeping in view the suggestions given by [6] and [5], we suggest the following recommendation for the implementation of the social cohesion in our country.

To foster such type of education it needs a real revolution in the whole system of education. It requires teachers who are genuine, open and secure human beings with essentially warm and favorable feelings about students. Initiation of such education does not depend upon his curriculum planning, nor upon his ability to deliver a good lecture but it depends on manifestation of certain effective characteristics, which exist in the interpersonal relationship between the teacher and the student, like genuineness, trust and acceptance, empathetic understanding and profound love. It is in consonance with [1]. Similar characteristics such as, to be protective of their own belief and more willing to listen to others; and to be less bureaucratic and more democratic are also required on the part of the administration and policy makers to make humanistic education possible. Access to education and vocational training and investment in education are needed in this regard.

It is true that, to bring such a revolution is not so easy. It is quite difficult to crack the diehard tendency among many teachers, educational administrators and policy makers to whom all these revolutionary ideas are simply unacceptable. But a beginning has already been made, what is required is to give this revolution some momentum with the sole focus on making education truly liberated and humanized.

\section{References}

[1] Easterly, et. al. (2006): Social Cohesion, Institutions and Growth: Center for Global Development, 18(2), 103 - 120. www. cgdev. org.

[2] Green, A. et.al. (2006): Education, Equality and Social Cohesion. A Comparative Analysis. Palgrave Macmillan Publications UK. ISBN: 9781-4039-87976.

[3] Green, A. et.al. (2001): Education and social Cohesion: Recentering and Debate. Peabody Journal of Education, 76(3 -4), 274-284.

[4] Kantzara, V. (2010): Ta Oria Tis Ekpaideusis. Dokimia. Ekdoseis Atrapos, Athena.

[5] Mohanty, S. B. (1979): Education for Human rights. University News, 37(49), 14-19.

[6] Naik, J. P. (1979): Perspective of Formal and Non-formal Education. Journal of workers Education (Nagpur), 14(2), 1-8.

[7] Putnam, R. D. (2004): Education, Diversity, Social Cohesion and Social Capital: Note for Discussion in Meeting of OECD Education Ministers, Raising the Quality of Learning for all, $18^{\text {th }}-19^{\text {th }}$ March, Dublin.

[8] Ruskin, John (1979): Quotes of John Ruskin on the Meaning of Education. www.goal4success.com/educationquotes/index.thml.

[9] Vasiliki, K. (2011): The Relation of Education to Social Cohesion. Social Cohesion and Development, 6(1), 37-50.

[10] Wolf, A. (2002): Does Education Matter? Myths about Education and Economic Growth. Penguins Books, London. 